\title{
Research on the Theory of Intelligent Management of University Physical Education Teaching Data
}

\author{
LIU Dongxu ${ }^{1, a}$, LI Jiayi ${ }^{2, b, *}$ \\ ${ }^{1}$ Department of Physical Education, Jilin Institute of Chemical Technology, Jilin Jilin China \\ ${ }^{2}$ College of Information and Control Engineering, Jilin Institute of Chemical Technology, Jilin Jilin China \\ a85169593@qq.com, ${ }^{b}$ washy59@sina.com, \\ *Corresponding author
}

\begin{abstract}
.
With the rise of artificial intelligence and the advent of the $5 \mathrm{G}$ era, the field of education is constantly incorpo rating new technologies and things. Teachers and students get more educational information from it and get $b$ etter teaching effect. However, in the physical education teaching, the traditional methods and means are still the main part. The acquisition and recording of teaching data is still in the stage of Stopwatch and pen-and-pa per recording, which is time-consuming and laborious, and also affects the teaching effect. This paper starts fr om the basic data of students in class, sums up the shortcomings of data management of students by teachers a t present, and puts forward the path and method of data intelligent management, to provide theoretical referen ce for promoting the development of P. E. teaching reform.
\end{abstract}

Keywords: physical education, intelligence, data management

\section{高校体育教学数据智能管理的理论研究}

\author{
刘东旭 ${ }^{1, a}$, 李佳怡 ${ }^{2, b, *}$
}

${ }^{1}$ 吉林化工学院体育教学部, 吉林, 吉林, 中国

2吉林化工学院信息与控制工程学院, 吉林, 吉林, 中国

a85169593@qq.com, ${ }^{b}$ washy59@sina.com,

“通讯作者

\section{中文摘要.}

随着人工智能的兴起和 $5 \mathrm{G}$ 时代的来临, 在教育领域不断的融入新的技术和事物, 从而促进教师和学生 获取更多的教育信息, 获得更好的教学效果。但在体育教学中, 传统的教学方法和手段依然是课堂的 主要部分, 体育教师对教学数据的获取和记录依然停留在秒表和纸笔记录阶段, 费时费力的同时, 也 影响了教学的效果。本文从体育教学中教师所必须获取和掌握的学生课内基本数据为出发点, 探讨现 阶段体育教学中教师对学生课内数据管理的不足之处, 整合体育教学数据智能化管理的实现路径及方 法, 为促进体育教学改革发展提供理论参考。

关键词: 体育教学; 智能化; 数据管理

\section{1. 引言}

教学改革的不断推进使传统教学模式逐步转变, 节 省时间的同时也提高了教学效率, 传统的粉笔黑板已经 逐步被电子教学设备替代, 实现教学的网络化信息化以 及便捷化 ${ }^{[1-2]}$ 。但区别于传统课堂教学的体育教学还停
留在传统的课堂教学模式中, 其教学环境的特殊性, 教 学对象的个性化差异始终对体育课堂有很大的影响, 数 据管理还停留在人工管理阶段, 传统的秒表和纸笔记录 依然是体育课堂获取教学数据的主要手段 ${ }^{[3]}$ 。AI技术的 不断推进和 $5 \mathrm{G}$ 时代的到来使各个领域都发生翻天覆地 的变化, 数据的获取传输处理变得更加方便快捷 ${ }^{[4-5]}$ 。 在体育教学中体育教师可利用移动设备、PC端结合可 穿戴设备获取学生课内各项指标数据, 通过对数据的处 
据体育教学的需要进行开发和设计 ${ }^{[10]}$ 。由于体育教学过 程中数据内容和种类繁杂, 所以系统需要实现的功能也 较多, 例如, 课程考试项目和学生信息的添加和修改, 学生成绩的获取记录分析, 成绩的分值换算以及教师学 生的导出。同时, 体育教学过程中学生生理指标物理指 标实时监测的查看和分析等。

\section{2 价值数据的获取和分析}

体育教学中价值数据分为测试类数据和身体指标 类数据两大类。测试类数据包括测试类型、测试项目以 及成绩管理等 ${ }^{[11]}$ 。通过对此类数据的采集和分析处理, 能够帮助教师获取学生的课程测试结果, 节省传统的纸 笔记录后利用大量时间逐一计算的过程，提高了成绩获 取和计算的效率和准确率 ${ }^{[12]}$ 。身体指标类数据包括学生 的物理指标和生理指标两类, 其中物理指标包含学生在 课内的运动轨迹距离速度和步数等, 生理指标包含学生 的运动心率血氧浓度血压等, 通过对两类指标的采集和 分析, 教师能够充分掌握教学过程中每个学生的实时身 体状态, 对学生身体状态的掌控便于教师根据实际情况 对教学过程进行调整和改变, 从而合理的控制课堂的负 荷和强度, 让体育教学更具机动性。

\section{3 教学过程中的试验与调试}

体育教学具有不确定性的特点, 在教学过程中会出 现许多突发情况, 需要教师根据实际情况及时做出判断 和解决 ${ }^{[13]}$ 。所以, 可穿戴设备和教学数据智能管理系统 也应在教学过程中的试验来找出存在的问题和不足, 并 在设计上予以修改调整, 来满足体育教学的各项数据需 求, 从而达到辅助教学的基本功能。

\section{4体育教学中的应用}

教师和学生依然使体育教学的两个重要部分, 辅助 教学手段要依靠教师和学生的熟练掌握和使用去实现 它功能的最大化 ${ }^{[14]}$ 。首先, 体育教师应转变观念, 从传 统的体育教学模式中走出来, 积极学习和掌握新的事 物, 意识到新事物给体育教学带来积极的作用。其次, 作为课堂主体的学生, 也应积极配合教师使用新的辅助 教学手段上课, 意识到这是对课堂的促进和帮助, 能够 最大程度的保证学生在课堂的人身安全, 提高课堂测试 的效率和成绩的准确率, 能够更清晰的看到自己的身体 状态和测试成绩。

教育部门和相关单位的管理者, 理应顺应时代的变 化, 对体育教学数据智能管理予以相关政策和资金上的 支持和投入, 并引进相关方面的人才, 实现多领域跨学 科的合作, 来促成AI在体育教学中的推广和应用。 
[10] Huang Youmin, Liu Lei, Guo Gengyang. Application Prospect Analysis of Intelligent Wearable Equipment in School Physical Education [J]. Sports Teachers and Friends, 2019,42(05):42-43.

[11] Pan Liping. Study on Optimization of Evaluation Index System for College Physical Education Curriculum Reform [J]. Zhejiang Physical Education Science, 2019,41(06):73-77.

[12] Wang Qiming. A wearable technology revolution is emerging in North America [J]. Global Outlook on Science and Technology Economy, 2013,28(10):1-8.

[13] Cao Xuefeng. Research on Problems and Improvement Strategies of Physical Education Teaching in Colleges and Universities at Present [J]. Neijiang Science and Technology, 2019,40(11):73-74.

[14] Chen Yu Ning. How to Improve the Effectiveness of High School PE Classroom Teaching [J]. Sports Fashion, 2019(10):163.
[2] Han Dandan, Ding Yuansheng. Modern teaching technology is indispensable to the cultivation of subject core literacy $[\mathrm{J}]$. Journal of Jilin Institute of Chemical Technology, 2019,36(08):31-33+87.

[3] Yan Bingshun. Factors Affecting the Development of Physical Education in Colleges and Universities in China and Countermeasures [J]. Intelligence, 2019(31):213.

[4] Wang Ning. Research on the Application and Development of Network Technology in College Physical Education [D]. Mudanjiang Normal University, 2014.

[5] Liu Qilong. Construction of Physical Education Information Management System for Newly-built Undergraduate Universities Based on Standardized Teaching $[\mathrm{J}]$. Education and Teaching Forum, 2015(19):12-13.

[6] Cai Yiyi. Application of Trigger in PPT Courseware [J]. Road to Success, 2012(22):81.

[7] Zhou Ping. Research on the Development and Application of Physical Education Management Information System in Colleges and Universities [D]. East China Normal University, 2006.

[8] Zou Xiaojiang. Overview of the Application of Artificial Intelligence Technology in Sports [J]. Science and Technology Information, 2019,17(08):119-120.

[9] Yuan Zhiliang. Research on the Application of Information Technology in Physical Education Curriculum Teaching in Colleges and Universities [C]. Professional Committee of Teaching Research of Guangxi Writing Association. Compilation of Results of 2019 Forum on Teaching Research and Teaching Writing Innovation (I). Professional Committee of Teaching Research of Guangxi Writing Association: Professional Committee of Teaching Research of Guangxi Writing Association, 2019:802-804. 